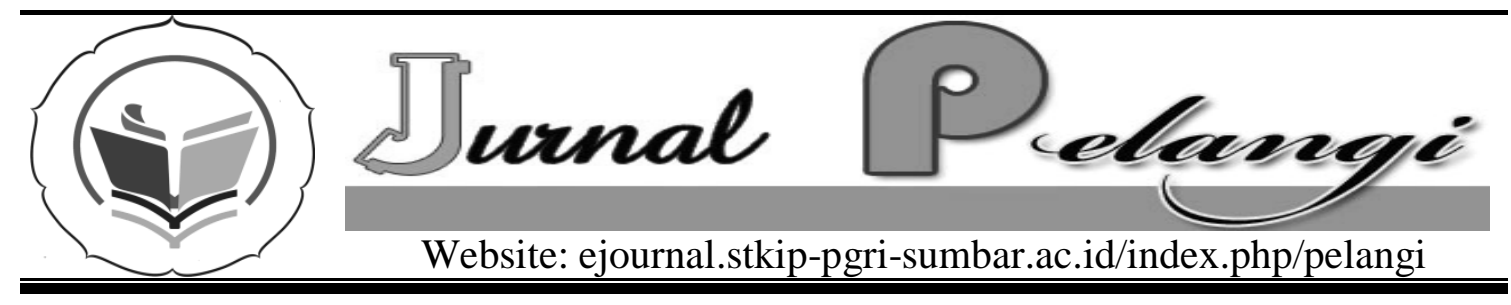

\title{
INFOKUS: UPAYA PENINGKATAN AKTIVITAS MAHASISWA DALAM PEMBELAJARAN PENDIDIKAN KEWARGANEGARAAN DI PERGURUAN TINGGI
}

\section{Budi Juliardi}

INFO ARTIKEL

\section{Diterima:}

Direview:

Disetujui:

Keyword:

Infocus, learning, activity, motivation

\section{PENDAHULUAN}

Undang-Undang
Republik Indonesia Nomor 20 tahun 2003 tentang Sistem Pendidikan

Nasional (Sisdiknas), Pasal 37 ayat (2) menyebutkan bahwa "Kurikulum pendidikan tinggi wajib memuat: (a) pendidikan Agama; (b) pendidikan Kewarganegaraan; dan (c) Bahasa". Dari isi Undang-Undang Sisdiknas ini jelas bahwa eksistensi Pendidikan Kewarganegaraan (selanjutnya disingkat dengan PKn) dalam kurikulum pendidikan tinggi adalah berdiri sendiri sebagai sebuah mata kuliah. PKn dalam pengertian sebagai civic education,

\section{Abstrak}

The use of media in the learning process should be base on an objective criterion which includes the learning goal (basic and standard competence), the learning activities and evaluation. This research is class experience in solving the decreasing motivation and enthusiasm. As a medium in eaching civics, infocus should be selected on the basis of its contens. The research was divided into two cycles, of which functional parameter through interactive model. The first cycle gave the expected results but needed to maximized. After their full participation in the lesson

$$
\text { secara substantif dan pedagogis }
$$
didesain untuk mengembangkan warganegara yang cerdas dan baik untuk seluruh jalur dan jenjang pendidikan, (Muhammad, S.B, 2009), termasuk juga bagi mahasiswa di perguruan tinggi.

Dalam rangka pengembangan warganegara yang cerdas dan baik, maka peningkatan kualitas pembelajaran mutlak dilakukan. Peningkatan kualitas pembelajaran dapat dilakukan dengan pertama kali meningkatkan motivasi belajar peserta didik. Dalam prosesnya, peningkatan kualitas pembelajaran dipengaruhi oleh media yang digunakan sebagai salah satu faktor 
penting kegiatan pembelajaran, selain factor lain yang pengaruhnya penting dalam aktivitas pembelajaran, seperti: guru/dosen atau fasilitator, input dan output peserta didik, serta sumber penunjang belajar lainnya. Media pembelajaran adalah segala sesuatu yang dapat digunakan dalam membantu proses pembelajaran, juga merupakan salah satu substansi yang ikut menentukan keberhasilan belajar.

Pemanfaatan media yang baik dalam proses pembelajaran harus didasarkan pada kriteria pemilihan yang objektif, berdasarkan tujuan pembelajaran (standar kompetensi dan kompetensi dasar) yang akan dicapai, strategi kegiatan pembelajaran, dan sistem evaluasinya. Faktor-faktor yang perlu dipertimbangkan dalam pemilihan (prioritas) pengadaan media adalah; relevansi pengadaan media, kelayakan pengadaan media, dan kemudahan pengadaan media (Rohani, 1997:28). Berdasarkan ketiga faktor tersebut, maka dalam memberikan prioritas pengadaan media perlu kiranya diadakan pengukuran untuk ketiga factor tersebut sesuai dengan jenis dan jenjang pendidikan. Maksudnya disesuaikan dengan karakteristik dan tingkat perkembangan peserta didik. Disadari bahwa setiap media, selain memiliki keunggulan, juga mempunyai kelemahan dan keterbatasan, sehingga pemilihan dan pemanfaatan media perlu memperhatikan kriteria sebagai berikut:

1. Tujuan; media hendaknya menunjang tujuan yang telah dirumuskan.

2. Ketepatgunaan (validitas); tepat dan berguna bagi pemahaman bahan yang dipelajari.

3. Keadaan peserta didik; kemampuan daya pikir dan daya tangkap peserta didik serta besar kecilnya kelemahan peserta didik perlu dipertimbangkan.

4. Ketersediaan; pemilihan perlu memperhatikan ada atau tidaknya media di sekolah atau lembaga serta mudah sulitnya diperoleh.

5. Mutu teknis; media harus memiliki kejelasan dan kualitas yang baik.

6. Biaya; hal ini merupakan pertimbangan bahwa biaya yang dikeluarkan apakah seimbang dengan hasil yang dicapai serta ada kesesuaian atau tidak (Rohani, 1997:30).

Infocus - hampir sama dengan media video atau media audiovisual yang dapat menampilkan gambar (baik slide dalam bentuk power point, film, dan lain sebagainya) yang disambungkan dari komputer atau laptop, saat ini semakin dikenal di kalangan masyarakat. Infocus dapat menanyangkan berbagai hal yang ingin ditampilkan dari computer/laptop kepada peserta didik berkaitan dengan materi yang akan diajarkan. Peserta didik biasanya mudah tertarik dengan hal-hal yang baru, termasuk dengan penggunaan media infocus. Ketertarikan ini dapat merangsang motivasi dan gairah untuk belajar.

Dengan demikian, media infocus menjadi salah satu hal yang penting untuk diperhatikan, termasuk penggunaannya dalam proses pembelajaran PKn di Perguruan Tinggi. PKn adalah mata kuliah umum yang tergolong ke dalam MKPK (Mata Kuliah Pengembangan Kepribadian) yang diberikan pada mahasiswa dan menjadi mata kuliah wajib di setiap perguruan tinggi di Indonesia, termasuk perguruan tinggi di Kota Padang, Sumatera Barat. PKn dimaksudkan untuk membentuk peserta didik menjadi manusia yang memiliki rasa kebangsaan dan cinta tanah air (Penjelasan Pasal 37 Ayat 1 UU RI No. 20 Tahun 2003).

Berdasarkan

Keputusan Dirjendikti No. 43/Dikti/Kep/2006, tujuan umum pembelajaran PKn di 
perguruan tinggi dirumuskan sebagai berikut:

1. Untuk membantu mahasiswa mengembangkan kompetensi untuk mengetahui ilmu pengetahuan, keterampilan, dan sikap kewarganegaraan serta nilainilai yang diperlukan dalam rangka menerapkan pengetahuan dan keahliannya dalam masyarakat

2. Membantu mahasiswa menjadi warga negara yang cerdas, demokratik berkeadaban (kebebasan yang beradab), bertanggung jawab, serta menciptakan kemampuan kompetitif bangsa di era globalisasi.

PKn yang berhasil diterapkan dengan baik dalam proses pembelajaran akan menumbuhkan sikap mental yang bersifat cerdas dan penuh tanggungjawab dari peserta didik dengan diiringi oleh perilaku sebagai berikut: 1) Beriman dan bertaqwa terhadap Tuhan Yang Maha Esa dan menghayati nilai-nilai filsafat bangsa; 2) Berbudi pekerti luhur, berdisiplin dalam masyarakat, berbangsa dan bernegara; 3) Bersikap rasional, dinamis dan sadar akan hak dan kewajiban sebagai warga; 4) Bersikap profesional yang dijiwai oleh kesadaran belanegara; 5) Aktif memanfaatkan ilmu dan teknologi serta seni untuk kepentingan kemanusiaan, bangsa dan negara (Subagyo, 2005:11).

Kondisi pembelajaran $\mathrm{PKn}$ di beberapa perguruan tinggi di Sumatera Barat, khususnya di Kota Padang selama ini dilakukan cukup baik dan berjalan normal. Demikian pula hasil belajar di setiap rombongan belajar (rombel) pun cukup memuaskan. Dosen dalam pembelajaran pada umumnya menggunakan media white board, laptop, OHP, dan lain sebagainya. Namun pada proses pembelajaran, dosen sering menemukan kelas berada pada titik keaktifan yang nol (rendah) di mana antusiasme mahasiswa yang menurun di kelas. Ketika diajak sharing mengenai sebab kekurangaktivan mereka, mahasiswa mengatakan bahwa terkadang mereka merasa jenuh, malas dan sulit mencerna materi yang diberikan. Sering kali mahasiswa mengalami kesulitan memahami materi, khususnya terkait dengan materi yang tidak hanya menekankan pada pemahaman konsep saja, seperti materi mengenai Filsafat pancasila, Identitas Nasional, HAM dan Rule of Law, Ggeopolitik, dan Geostrategi.

Kesulitan dan kendala di atas, akan berdampak negatif jika tidak dicari solusinya. Misalnya menurunnya motivasi mahasiswa dalam proses pembelajaran hingga penurunan hasil belajar. Seperti halnya pembelajaran di tingkat sekolah dasar yang lebih berhasil dengan menggunakan media audio visual - dari beberapa hasil penelitian - maka penulis mencoba mengidentifikasi, membuat, dan menayangkan slide dalam bentuk power point serta mengumpulkan film-film berdurasi pendek yang kiranya dapat dilihat dan ditelaah lebih lanjut oleh mahasiswa dalam pembelajaran PKn dengan menggunakan media infokus.

Berdasarkan hal tersebut, maka penelitian dilaksanakan ini untuk meningkatkan motivasi, antusiasme, keaktifan dan kualitas pembelajaran PKn dengan pemanfaatan media infokus. Berpijak dari hal ini, permasalahan yang ingin dikaji dalam penulisan ini adalah; (1) Apakah media infocus dapat meningkatkan aktivitas mahasiswa dalam proses pembelajaran PKn? (2) Apakah media infocus dapat meningkatkan motivasi mahasiswa dalam proses pembelajaran $\mathrm{PKn}$ ? (3) Kendala-kendala apa saja yang 


\section{Jurnal Pelangi}

dihadapi dalam penggunaan media infocus pada pembelajaran PKn?

\section{LANDASAN TEORI}

Media Pembelajaran

Media berasal dari bahasa latin merupakan bentuk jamak dari "Medium" yang secara harfiah berarti "Perantara" atau "Pengantar" yaitu perantara atau pengantar sumber pesan dengan penerima pesan. Beberapa ahli memberikan definisi tentang media pembelajaran. Schramm (1977, dalam Akhmad Sudrajat, 2008:1) mengemukakan bahwa media pembelajaran adalah "teknologi pembawa pesan yang dapat dimanfaatkan untuk keperluan pembelajaran". Briggs (1977, dalam Akhmad Sudrajat, 2008:1) berpendapat bahwa media pembelajaran adalah "sarana fisik untuk menyampaikan isi/materi pembelajaran seperti: buku, film, video dan sebagainya". Sedangkan, National Education Associaton (1969, dalam Akhmad Sudrajat, 2008:1) mengungkapkan bahwa media pembelajaran adalah "sarana komunikasi dalam bentuk cetak maupun pandang-dengar, termasuk teknologi perangkat keras". Dari ketiga pendapat ini dapat disimpulkan bahwa media pembelajaran adalah segala sesuatu yang dapat menyalurkan pesan, dapat merangsang fikiran, perasaan, dan kemauan peserta didik sehingga dapat mendorong terciptanya proses belajar pada diri peserta didik.

Brown (1973, dalam Akhmad Sudrajat, 2008:2) mengungkapkan bahwa media pembelajaran yang digunakan dalam kegiatan pembelajaran dapat mempengaruhi efektivitas pembelajaran. Pada mulanya, media pembelajaran hanya berfungsi sebagai alat bantu untuk mengajar (berupa alat bantu visual. Sekitar pertengahan abad Ke-20, usaha pemanfaatan visual dilengkapi dengan penggunaan alat audio, sehingga lahirlah alat bantu audio-visual. Sejalan dengan perkembangan ilmu pengetahuan dan teknologi (IPTEK), khususnya dalam bidang pendidikan, saat ini penggunaan alat bantu atau media pembelajaran menjadi semakin luas dan interaktif, seperti adanya computer/laptop dan infokus.

Santoso S. Hamijaya (Rohani, 1997: 11) mengklasifikasilkan media menurut cara penggunaannya, yaitu:

1. Media dan teknologi pendidikan yang penggunannnya secara massal. Contoh: televisi melalui siaran terbuka, siaran tertutup (CCTV), stratovition dengan stasiun penyiar dari pesawat terbang yang berkeliling di atas daerah operasi siaran, radio, slide, dan lain-lain.

2. Media tekonologi pendidikan yang cara penggunannya secara individual. Contoh: Laboratorium bahasa, laboratorium pusat sumber belajar, dan lain-lain.

3. Media teknologi pendidikan yang penggunaannya secara konvensional.

4. Media pendidikan baru.

a. Ruang kelas otomatis: ruang kelas yang dapat diubah-ubah fungsinya secara otomatis dengan menekan tombol.

b. Sistem proyeksi berganda: suatu sistem proyeksi ruang melengkapi ruang kelas secara otomatis.

c. Sistem interkomunikasi.

Dari pengklasifikasian tersebut dapat dilihat bahwa media dapat dibedakan menjadi beberapa jenis, yaitu: 1) Media asli dan tiruan, 2) Media grafis, 3) Media Proyeksi (visual aids); proyeksi diam dan proyeksi gerak, 4) Media dengar (audio media), 5) Media pandang dengar (audio visual aids), 6) Media 
Cetak (Printed materials), dan 7) Media bentuk papan (Mudhoffir, 1986:34).

Infokus sebagai Media dalam Proses Pembelajaran Bagi perguruan tinggi, media pembelajaran relatif lebih lengkap ketersediaannya, mengingat kebutuhan dalam pembelajaran. Salah satunya adalah infokus. Beberapa alasan untuk menggunakan infokus dalam pembelajaran adalah bahwa infokus merupakan media pembelajaran yang mutakhir dalam bentuk yang mudah dipahami dan menarik, disamping buku, gambar, video, dan lain-lain. Selain itu, penggunaan media infokus dalam proses pembelajaran juga dapat menciptakan suasana yang menyenangkan, merangsang, dan membangkitkan ide- ide baru. Bahkan cara penyajian materi melalui media infokus sangat hidup, menarik, dan mengundang keterlibatan peserta didik, baik melalui tayangan slide dalam bentuk power point maupun penayangan film durasi pendek yang diperlihatkan. Berdasarkan uraian ini, dapat digarisbawahi bahwa penggunaan infokus dapat dijadikan sebagai media yang efektif dalam proses pembelajaran, khususnya pembelajaran PKn.

$\begin{array}{lll}\text { Dalam menggunakan media } \\ \text { infokus, } & \text { pendidik } & \text { wajib }\end{array}$ menyertakannya dengan computer atau laptop. Penyampaian materi dalam pembelajaran dengan menggunakan media infokus harus lebih dahulu dipersiapkan dan kemudian baru ditayangkan di kelas.

\section{METODE PENELITIAN}

Penelitian ini merupakan penelitian tindakan kelas (PTK), yang bertujuan untuk memecahkan persolan berkurangnya keaktifan dan gairah mahasiswa dalam belajar, serta untuk menekan kesulitan belajar mahasiswa dalam proses pembelajaran. Penelitian dilaksanakan di Sekolah Tinggi Keguruan dan Ilmu Pendidikan (STKIP) PGRI Sumatera Barat, pada Mahasiswa Program Studi Sosiologi Sesi 2009/F, di Gedung B204, dengan sumber data mahasiswa dan dosen PKn pada tahun ajaran 2009/2010. Data yang diperoleh dalam penelitian ini dianalisis secara kualitatif dengan teknik analisis kategorial dan fungsional melalui model interaktif. Data diambil dengan menggunakan lembar observasi, yang diuraikan secara deskriptif dengan menganalisis aspekaspek pengamatan yang telah diisi peneliti berdasarkan kenyataan di kelas. Lembar evaluasi kegiatan mahasiswa dianalisis dengan membaca cek poin yang diisi oleh mahasiswa peserta kuliah. Data wawancara dianalisis dengan merumuskan kembali atau menyimpulkan hasil wawancara. Selain itu, penulis juga menyertakan dokumentasi foto hasil pelaksanaan penelitian. Adapun variabel yang diteliti meliputi:

1. Peningkatan aktivitas belajar mahasiswa yang diukur dengan lembar observasi evaluasi mahasiswa yang meliputi keaktivan mahasiswa dalam bertanya jawab baik dengan dosen maupun dengan sesame mahasiswa dalam forum diskusi saat proses pembelajaran berlangsung menggunakan media infokus.

2. Peningkatan gairah belajar mahasiswa yang diukur dengan lembar observasi evaluasi mahasiswa yang meliputi antusiasme mahasiswa saat proses pembelajaran berlangsung menggunakan media infokus.

3. Penguasaan aspek kognisi diukur dari jawaban, pertanyaan lisan, atau tugas.

4. Penguasaan aspek psikomotorik diukur dari kemampuan 
mengidentifikasi masalah-masalah seperti masalah dalam pelaksanaan HAM, maslah dalam pelaksanaan demokrasi yang telah ditayangkan melalui penggunaan media infokus.

Penelitian tindakan kelas ini direncanakan dengan beberapa siklus (sesuai kebutuhan). Setiap siklus terdapat langkah-langkah rencana tindakan sebagai berikut:

1. Perencanaan tindakan siklus I.

Perencanaan tindakan pada siklus I meliputi:

a. Membuat rencana, menyangkut skenario pemanfaatan media infokus sebagai media dalam mata kuliah PKn, dengan menentukan materi yang akan diajarkan.

b. Membuat slide dalam bentuk power point dan memilih film durasi pendek yang akan ditayangkan menggunakan media infokus dalam proses pembelajaran PKn, misalnya disesuaikan dengan standar kompetensi, kompetensi dasar, dan materi perkuliahan.

c. Mempersiapkan materi kuliah sesuai silabus, lembar kerja, dan fasilitas

d. serta segala hal yang diperlukan dan bahasan yang akan memanfaatkan media infokus.

e. Menyediakan format evaluasi.

f. Hasil dari pertemuan awal akan digunakan untuk menyusun strategi, rencana dan skenario, serta studi kelayakan tindakan pada pertemuan berikutnya.

2. Pelaksanaan Tindakan

Pada siklus I, tim peneliti melakukan tindakan sebagai berikut:

a. Apresepsi dengan mengarahkan pemahaman mahasiswa tentang materi yang akan di bahas.

b. Memberikan penjelasan kepada mahasiswa tentang tujuan penggunaan infokus sebagai media pada mata kuliah PKn dalam pembelajaran.

c. Memberikan stimulus kepada mahasiswa melalui beberapa pertanyaan yang relevan dengan materi mata kuliah PKn yang akan diajarkan.

d. Mengimplementasikan penggunaan infokus sebagai media pada mata kuliah PKn.

e. Pembentukan kelompok-kelompok diskusi yang diberi tugas masingmasing untuk mendiskusikan materi yang dapat difasilitasi dengan penggunaan media infokus.

f. Masing-masing kelompok mempresentasikan hasil diskusi secara bergantian.

g. Pemberian tugas kepada mahasiswa untuk merangkum materi yang terkandung dalam slide yang ditayangkan menggunakan media infokus.

h. Evaluasi.

\section{Observasi}

Dalam penelitian tindakan kelas ini, tim peneliti melaksanakan observasi sekaligus evaluasi terhadap pelaksanaan tindakan dengan menggunakan lembar observasi dan evaluasi yang diisi oleh dosen dan mahasiswa. Dalam hal ini termasuk mempersiapkan media lain seperti alat perekam yang dapat dimanfaatkan secara maksimal.

Tahap observasi pada siklus ini meliputi:

a. Pengamatan terhadap pelaksanaan proses pembelajaran dengan menggunakan media infokus pada mata kuliah PKn.

b. Pengamatan terhadap sikap dan perilaku mahasiswa selama proses pembelajaran berlangsung.

c. Pelaksanaan penilaian terhadap semua aktivitas mahasiswa pada saat dan pasca mengimplementasikan infokus 
sebagai media pada mata kuliah PKn dengan menggunakan lembar penilaian.

\section{Refleksi}

Setelah melakukan sintesis dan analisis data yang ada (hasil wawancara, lembar observasi dan lembar evaluasi), kemudian dosen (tim peneliti) dan mahasiswa merefleksikan diri apakah kegiatan pembelajaran dengan bantuan media infokus pada mata kuliah PKn yang sudah dilakukan, berhasil menambah dan meningkatkan aktivitas dan gairah belajar mahasiswa serta mampu memberi solusi dalam masalah pembelajaran PKn atau belum. Dengan mempelajari hal tersebut dapat diketahui kelemahan/ kekurangan dan kelebihan pelaksanaan tindakan yang dilakukan untuk bahan pelaksanaan siklus selanjutnya.

Pelaksanaan siklus I ini akan dievaluasi, dilaksanakan secara berulang-ulang dan dilihat hasilnya dalam pelaksanaan siklus berikutnya (siklus ke 2), jika masih dianggap ada kekurangan maka dilaksanakan siklus berikutnya dilaksanakan. Langkah dalam setiap siklus tersebut dapat digambarkan sebagai berikut:

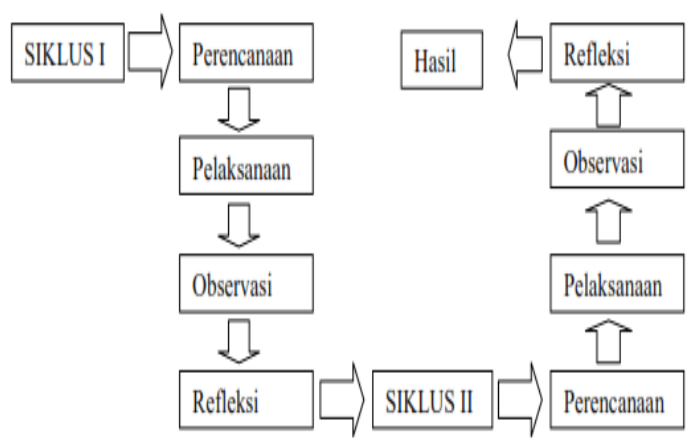

\section{HASIL DAN PEMBAHASAN}

Tujuan umum penelitian ini adalah meningkatnya kualitas belajar mahasiswa peserta mata kuliah PKn. Untuk mewujudkan tujuan tersebut, maka dipilih metode diskusi setelah penggunaan/pemanfaatan media infokus. Hal ini dilakukan untuk melihat tingkat keaktivan dan gairah belajar mahasiswa setelah menggunakan media infokus. Keaktivan mahasiswa dapat dilihat dalam pemberian umpan balik dan pemberian pendapat mereka terkait dengan slide dan film durasi pendek yang ditayangkan melalui media infokus untuk mengantarkan pemahaman mereka terhadap materi. Selain itu, setelah diskusi mahasiswa dapat menyimpulkan materi yang diberikan.

Hasil penelitian ini diharapkan dapat memberikan alternatif tentang penggunaan media pembelajaran yang menyenangkan bagi mahasiswa dengan melihat tayangan melalui media infokus. Mahasiswa melihat dan menyaksikan tayangan yang diberikan berkaitan dengan matei yang dipelajari. Selanjutnya mahasiswa mendiskusikan dan merumuskan sendiri apa yang telah mereka lihat dalam tayangan infokus. Selain itu mahasiswa akan secara lebih mudah menerima materi dalam pembelajaran. Sebaliknya, dosen juga lebih mudah dalam pembelajaran, dimana dosen benar-benar berperan sebagai fasilitator saja. Mahasiswa hanya butuh arahan mengenai hal-hal yang telah mereka lihat dan akhirnya dirumuskan sendiri. Dosen hanya memikirkan bagaimana strategi dalam menyampaikan materi saja.

Sebelum tindakan dilakukan, dosen menjelaskan terlebih dahulu rencana dilaksanakannya penelitian. Hal ini dilakukan untuk mendapatkan data pra- tindakan pembelajaran, untuk menyamakan presepsi rencana tindakan, dan mendesain tindakan yang sesuai saat penelitian tindakan dilaksanakan. Selain itu, juga dilakukan untuk mengetahui kondisi perkuliahan PKn yang berlangsung selama ini dan masalahmasalah yang ada dan solusi tindakan yang seharusnya ditempuh. Dosen 
menguraikan kepada peserta kuliah tentang penelitian yang akan dilakukan, serta menetapkan pertemuan ke -10 sebagai awal tindakan kelas atau siklus I. Mahasiswa yang menempuh mata kuliah PKn pada prodi Sosiologi sesi

2009/F sebanyak 35 mahasiswa dibagi menjadi 7 kelompok dengan keanggotaan masing-masing kelompok 5 orang. Rencana atau skenario tindakan diimplementasikan pada pertemuan ke10 dengan materi pembelajaran HAM dan Rule of Law. Peneliti bersamasama dengan tim (kolaborator) atau partisipan melaksanakan kegiatan sebagaimana yang sebelumnya telah ditulis/ditetapkan dalam skenario pembelajaran. Dalam tahapan ini juga, ditetapkan slide dalam bentuk power point dan film durasi pendek yang diakses dari YouTube tentang "Pencuri HP dihajar Masa" yang dapat menunjang pembelajaran, khususnya mengenai HAM.

\begin{tabular}{lr}
\multicolumn{1}{c}{ Apersepsi } & $\begin{array}{r}\text { dengan } \\
\text { kuliah }\end{array}$ \\
disampaikan pada & materi
\end{tabular}
pemahaman awal mahasiswa tentang hakekat dan pengertian HAM. Fokus penelitian tindakan ini adalah aktivitas, motivasi, antusiasme mahasiswa peserta kuliah. Aktivitas pembelajaran menyangkut kegiatan belajar mengajar di kelas dengan indikator aktivitas belajar adalah keterlibatan mahasiswa dalam pembelajaran (berada dalam tugas, mengambil giliran, dan berbagai tugas, mendorong partisipasi, mendengarkan dengan aktif, dan bertanya), penggunaan sumber belajar, dan interaksi belajar. Hasil belajar yang berhubungan dengan aspek kognitif (pemahaman terhadap materi perkuliahan), aspek afeksi, (rasa senang belajar, tidak tertekan, antusias mengikuti kuliah, disiplin dalam tugas, kehadiran perkuliahan), dan aspek psikomotor (sikap dan perilaku). Selain itu juga dilakukan pre test (dosen bertanya) untuk mengetahui kemampuan mahasiswa diawal pertemuan. Setelah pre test, dosen menjelaskan materi yang telah ditayangkan dalam bentuk slide power point dan menjelaskan maksud pemutaran film durasi pendek melalui penggunaan media infokus dan juga menjelaskan cara kerja kelompok yang telah dibentuk.

Untuk lebih rincinya mengenai langkah-langkah yang dilaksanakan pada

tahapan ini adalah sebagai berikut:

1. Penayangan slide dalam bentuk power point yang berhubungan dengan HAM, termasuk pengertian dan hakikat HAM, sejarah perkembangan HAM, dan lain-lain.

2. Pemutaran film durasi pendek dengan judul "Pencuri HP dihajar Masa".

Dosen dan observer melakukan pengamatan terhadap situasi kelas. Perhatian kelas, menjadi tertuju kepada film yang diputar dengan menggunakan media infokus. Mahasiswa terlihat santai, menikmati pemutaran film, namun tidak terdapat aktifitas lain yang dilakukan mahasiswa. Film diputar dengan durasi 3 - 5 menit.

3. Setelah pemutaran film selesai, mahasiswa duduk berdasarkan kelompok (kelompok telah ditetapkan sebelumnya).

4. Dalam kelompok, dosen meminta mahasiswa untuk mendiskusikan beberapa materi yang telah diberikan terkait dengan materi serta permasalahan yang harus dipecahkan oleh mahasiswa dalam kelompok. Mahasiswa kemudian 
mendiskusikan tentang pendapat mereka mengenai film durasi pendek yang telah diputar, dan pemahaman mereka tentang pengertian, makna HAM serta cara dan contoh perilaku menjunjung tinggi HAM dan perilaku yang tidak menjunjung tinggi HAM yang dapat dilakukan oleh warga Negara Indonesia. Selain itu mahasiswa dalam kelompok juga membahas hak dan kewajiban warga Negara dan pemerintah dalam upaya perlindungan HAM.

5. Pada point a sampai dengan c di atas, dosen pengampu dan peneliti selaku observer mengawasi situasi kelas. Mengamati dengan cermat perubahan perilaku maupun situasi kelas.

6. Dosen pengampu juga memberikan soal, yang harus didiskusikan oleh kelompok.

7. Setelah kerja kelompok selama 25 menit, kemudian dosen memberikan kesempatan kepada kelompok-kelompok melalui juru bicaranya untuk memaparkan pendapat mereka.

8. Kelompok lain dimotivasi untuk memberikan pendapat tentang uraian atau pendapat kelompok pemapar.

9. Dirumuskan simpulan bersama oleh kelas tentang materi, berdasarkan hasil diskusi kelas.

10. Di akhir pertemuan, dosen memberikan tugas yang harus dikerjakan oleh individu tentang materi Hak dan Kewajiban Warga Negara. Tugas ini diberikan, agar mahasiswa mempersiapkan diri sebelum pembelajaran pada pertemuan yang akan datang.

Temuan dalam penelitian ini dapat diidentifikasi melalui pemantauan selama pengalaman belajar berlangsung, seperti; pertama, antusias belajar mahasiswa mengalami peningkatan dari pertemuan sebelumnya, dilihat dari perhatian mahasiswa yang terfokus pada pembelajaran. Kedua, saat kerja dalam kelompok, masing-masing mahasiswa terlibat secara aktif dalam diskusi yang diselenggarakan. Walaupun masih ditemukan beberapa mahasiswa yang pasif, jika tidak ditanya oleh temannya sekelompok dan dosen. Dari hasil pengamatan, lembar observasi dan evaluasi di kelas, dari 35 mahasiswa terdapat 25 mahasiswa $(71 \%)$ yang terlibat secara aktif dalam pembelajaran masing-masing kelompok. Ketiga, saat pemaparan tugas kelompok, ditemui kesulitan dalam kelas, yakni sebagai juru bicara yang memaparkan tugas, selalu mahasiswa yang itu-itu saja (yang aktif dalam keseharian). Padahal harapan di awal penelitian, semua mahasiswa mau dan berani untuk aktif dalam pembelajaran. Namun kelas menyatakan puas mengikuti proses pembelajaran. Keempat, dalam hasil kerja kelompok, ternyata hanya disalin oleh salah satu mahasiswa. Sedangkan mahasiswa lainnya ternyata tidak membuat catatan tentang materi pembelajaran. Kelima, evaluasi dilakukan dikelas, dengan meminta pendapat mahasiswa peserta kuliah tentang pembelajaran. Beberapa mahasiswa menyatakan masih merasa tegang saat proses pembelajaran. Menurut mereka, ini terjadi karena ada dosen lain yang juga mengawasi proses belajar, dan scenario pembelajaran ini masih terasa kaku dan menegangkan. Kemudian, ini berakibat pada situasi kelas yang kurang kondusif.

Berpijak dari pengalaman belajar di atas, kemudian disepakati bersama antara dosen, tim dan mahasiswa peserta kuliah bahwa pada pertemuan berikutnya akan segera dilaksanakan siklus 
berikutnya (kedua) untuk mengoptimalkan pengalaman belajar mahasiswa yang telah terjadi di siklus sebelumnya. Setelah pembelajaran berakhir, dosen dan tim melakukan refleksi. Berbagai evaluasi dilakukan terhadap proses pembelajaran yang berlangsung dan diperoleh simpulan bahwa pembelajaran dilaksanakan sesuai dengan rancangan skenario dan proses pembelajaran sudah relatif lebih baik dari pembelajaran sebelumnya.

Siklus berikutnya dilaksanakan pada pertemuan selanjutnya. Dalam siklus kedua, membahas materi Hak dan Kewajiban Warga Negara. Ditayangkan slide dalam bentuk power point tentang pengertian hak dan kewajiban, pengertian warga Negara, dan lain-lain. Selanjutnya diputar film durasi pendek tentang "Pedagang kakilima yang selalu diusir oleh Satpol PP di Jakarta" yang dianggap mengabaikan hak warga Negara untuk mendapatkan penghasilan dan penghidupan yang layak. Film ini didapat dari YouTube dan kemudian diedit untuk pembelajaran. Durasi waktunya 3 menit. Pelaksanaan siklus ini membawa hasil yang positif, dan proses atau pengalaman belajar mahasiswa sebagai berikut:

1. Mahasiswa terlihat siap dalam mengikuti perkuliahan, ini dapat dilihat dari jawaban-jawaban yang diberikan saat dosen memberikan pertanyaan tentang materi minggu yang lalu, dan menjajagi pemahaman mahasiswa tentang materi kuliah yang akan disampaikan selain itu mahasiswa menjawab pertanyaan dosen atas tugas-tugas yang diberikan di siklus sebelumnya.

2. Mahasiswa menjawab pertanyaanpertanyaan dari dosen dengan penalaran yang tajam, baik secara individu maupun kelompok. Lebih dari $94 \%$ peserta kuliah aktif berpartisipasi dalam kelompoknya.

3. Mahasiswa mengikuti jalannya pembelajaran dengan baik, dan kualitas kerjasama kelompok yang meningkat setelah penggunaan media infokus.

4. Frekuensi dan kualitas pembelajaran ditengah dan diakhir pembelajaran meningkat dari siklus/pertemuan sebelumnya.

Setelah pembelajaran siklus kedua ini dilaksanakan, kemudian sharring/refleksi kembali dilakukan di kelas terkait dengan proses pembelajaran antara tim dan mahasiswa.

Dalam penelitian tindakan kelas ini, mahasiswa diminta berpartisipasi dalam evaluasi, sebab mahasiswalah yang dapat merasakan atau melakukan perubahan kearah lebih baik atau sebaliknya. Demikian dari pendapat mahasiswa dan pengamatan tim saat pembelajaran, siklus kedua disimpulkan;

1. Meningkatnya aktivitas mahasiswa yang terlihat dari keaktivan bertanya dan menjawab pertanyaan dalam forum diskusi maupun saat dosen menayangkan slide menggunakan infokus

2. Meningkatnya kemampuan analisis dan daya berfikir kritis mahasiswa peserta kuliah.

3. Timbulnya rasa puas atas bahan yang dipelajari dalam kuliah.

Berdasarkan masukan mahasiswa di atas akhirnya disepakati bersama bahwa pembelajaran dengan menggunakan media infokus, cukup dilaksanakan dengan dua siklus, karena sudah sepakati membawa dampak positif yang maksimal, baik bagi mahasiswa maupun bagi dosen. Keberhasilan siklus pertama dan siklus kedua ini, juga nantinya dapat disimpulkan dari hasil belajar mahasiswa saat pelaksanaan 
evaluasi test di tengah semester. Namun, karena keterbatasan waktu, penelitian ini belum sampai dapat melaporkan apakah peningkatan kualitas pembelajaran dengan menggunakan media infokus ini diikuti oleh peningkatan hasil ujian mahasiswa atau tidak.

Dari proses pembelajaran di siklus pertama dan kedua yang terjadi, terdapat beberapa peristiwa positif yang terjadi dalam pembelajaran, yakni adanya suasana pembelajaran yang kondusif dan positif, yang meliputi aktivitas dan antusiasme mahasiswa dalam kerja kelompok, yang dipicu oleh adanya pemahaman materi oleh masingmasing individu dalam pencapaian tujuan belajar. Selain itu, terwujud pula akuntabilitas individual. Pembelajaran dengan menggunakan media infokus, yang diikuti dengan diskusi kelompok merupakan tampilan dari pembelajaran kooperatif. Meskipun demikian, penilaian ditujukan untuk mengetahui penguasaan mahasiswa terhadap materi kuliah secara individual. Walaupun evaluasi tidak dapat dilaksanakan karena keterbatasan waktu penelitian. Penilaian secara individual tersebut selanjutnya disampaikan oleh dosen kepada mahasiswa. Ini berbeda dengan pembelajaran tradisional, dimana akuntabilitas individual sering diabaikan, sehingga tugas-tugas sering diborong oleh salah seorang anggota kelompok, sedangkan anggota kelompok lainnya hanya "enak- enak" saja atas keberhasilan temannya yang dianggap "pemborong".

Dari pelaksanaan penelitian, terdapat beberapa kendala dalam pembelajaran dengan menggunakan media infokus pada mata kuliah PKn yang kemudian dapat diatasi pada pelaksanaan siklus berikutnya, yakni;

1. Dalam proses pembuatan slide menggunakan power point dan pemilihan film durasi pendek yang akan ditayangkan memerlukan pertimbangan yang maksimal oleh dosen ketika memilih film apa yang cocok dan dapat dipilih menjadi media dalam pembelajaran. Tentu saja tidak semua film dapat dipilih sebagai media pembelajaran dan tidak semua film dapat menjadi media disemua materi pokok perkuliahan. Pemilihan film harus disesuaikan dengan materi pokok perkuliahan. Seperti saat menentukan pilihan film durasi pendek yang harus ditayangkan ketika membahas materi tentang HAM.

2. Tidak semua materi pokok dalam perkuliahan dapat disajikan dengan film durasi pendek. Kesulitan dalam memilih dan menetapkan film, menuntut dosen kreatif dan aktif mencari tema-tema film yang dapat digunakan untuk pembelajaran.

\section{SIMPULAN DAN SARAN Simpulan}

Setelah pelaksanaan pembelajaran dengan penggunaan media infokus, diperoleh simpulan-simpulan sebagai berikut:

1. Pembelajaran dengan menggunakan media infokus dapat meningkatkan aktifitas dan kualitas pembelajaran bagi mahasiswa peserta kuliah. Hal ini terlhat dari keaktivan mahasiswa dalam bertanya jawab baik saat dosen menayangkan slide menggunakan infokus maupun dalam diskusi kelompok.

2. Pembelajaran dengan menggunakan media infokus dapat meningkatkan gairah belajar mahasiswa peserta kuliah. Hal ini terlihat dari antusiasme dan semangat belajar mahasiswa saat dosen menggunakan media infokus. 
3. Terdapat beberapa kendala dalam mengimplementasikan penggunaan infokus sebagai media pembelajaran, seperti dalam hal pembuatan slide dalam bentuk power point dan pemilihan film durasi pendek yang harus hati-hati karena tidak semua materi pokok dalam pembelajaran dapat disajikan dengan menggunakan film sebagai media.

\section{Saran}

Berpijak dari pengalaman di atas,
saran yang direkomendasikan jika dilaksanakan kembali perkuliahan/ pembelajaran dengan menggunakan media infokus adalah;

1. Perlunya persiapan penguasaan materi yang akan disajikan dengan menggunakan media infokus sebelum pembelajaran dilaksanakan di kelas. Ini dapat disiasati dosen dengan memberikan tugas-tugas kepada mahasiswa dipertemuan sebelumnya.

2. Dosen harus memeriksa slide dalam bentuk power point yang telah dibuat dan melihat tayangan film durasi pendek yang akan diputar dengan menggunakan media infokus, sehingga dapat menyesuaikan dengan materi

\section{DAFTAR PUSTAKA}

\author{
Ahmad Sudrajat. 2008. "Media \\ Pembelajaran" (Online) \\ dalam \\ http://akhmadsudrajat.wordpress.co \\ $\underline{\mathrm{m} / 2008 / 01 / 12 / \text { media-pembelajaran/. }}$ \\ diakses tanggal 2 September 2010. \\ Mudhoffir. 1986. Prinsip-prinsip \\ pengelolaan Sumber Belajar. \\ Jakarta: PT. Remaja Rosdakarya. \\ Muhammad, S.B. 2009. Paradigma PKn \\ sebagai Wahana Sistematik \\ Pendidikan Demokrasi. (Online) \\ dalam http://muhammadsb- \\ tekhnologipendidikan.blogspot.com/ \\ 2009/03/paradima-pendidikan-
}

kewarganegaraan.html. diakses tanggal 2 September 2010.

Rohani, Ahmad. 1997. Media Instruksional Edukatif. Jakarta: PT Rineka Cipta. Subagyo. 2005. Pendidikan Kewarganegaraan. Semarang: UPT UNNES Press. Surat Keputusan Dirjendikti No. 43/Dikti/Kep/2006 tentang Kelompok Mata Kuliah Pengembangan Kepribadian.

UU RI No. 20 Tahun 2003 tentang Sistem Pendidikan Nasional. 